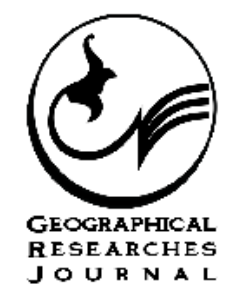

\title{
The Analysis of Spatial Distribution Pattern of Ardabil Province Industries by Spatial Statistics in GIS Environment
}

\section{ART I C LE INF O}

\section{Article Type}

Original Research

\section{Authors}

Noori S. ${ }^{1} M A$,

Mohammadi A. ${ }^{* 1} P h D$
How to cite this article

Noori S, Mohammadi A. The Analysis of Spatial Distribution Pattern of Ardabil Province Industries by Spatial Statistics in GIS Environment. Geographical Researches Quarterly Journal. 2019, 34(1):97-108.
${ }^{1}$ Department of Geography, Faculty of Humanities, University of Mohaghegh Ardabili, Ardabil, Iran

\section{*Correspondence}

Address: Department of Geography, Faculty of Humanities, University of Mohaghegh Ardabili, Daneshgah Boulvared, Ardabil, Iran Phone: -

Fax:

a.mohammadi@uma.ac.ir

\section{Article History}

Received: July 04, 2018

Accepted: December 16, 2018

ePublished: February 05, 2019

\section{A B S T R A C T}

Aims \& Backgrounds Unbalanced spatial distribution of industries in most regions of the developing countries can be have undesirable economic, environmental, and social effects. Understanding the spatial distribution patterns of industries is essential for their planning and distribution in the regions. The main aim of the present study is to analyze the distribution and spatial patterns of Ardabil province industries. Another aim of this study is to identify the main hubs of industries and the relationship between the spatial distribution of industries with economic, social and environmental variables.

Methodology This is a descriptive-analytical research. The statistical population of this research includes 1,700 active industrial spaces in Ardebil province. The data of these industrial spaces were obtained from the organization of industry, mining, and trade of Ardebil province and recorded in the geographic information system (GIS). Spatial statistical methods such as standard distance, Moran's spatial correlation index, General G* ord statistical model, and geographic weighted regression (GWR) model were used.

Findings a) The spatial distribution pattern of industries in Ardebil province is highly unbalanced and cluster; b) The geographic distribution of the industry is North-South; c) The focus of industrial spaces is towards the central parts of the province, C) Ardebil is the dominant center of attraction of industrial activities; d) There is a significant relationship between population variables, migration rate, urbanization rate, employment rate in industrial sector, topography and hydrology, with the distribution pattern of industries.

Conclusion Distribution of industries in Ardebil province is clustered and unbalanced.

Keywords Spatial Analysis; Pattern and Distribution; Industries; Spatial Statistics; Ardebil Province; GIS; Ardebil Province

\section{I T A T I O N L I N KS}

[Akbari M; 2009] What is land use ...; [Akhavan H \& Nazari R; 2007] Performance of Industrial ...; [AlHassan MR \& Diao X; 2007] Regional disparities in ...; [Yazdani MH; 2014] Analysis and leveling ...; [Anselin L; 1999] Spatial econometrics ...; [Apostolache MA; 2014] Regional development in ...; [Ardabil Industrial Townships Company; 2011] Report of the comprehensive ...; [Asgary A; 2011] Space statistics analysis ...; [Bresnahan T, et al.; 2001] Old economy' inputs ...; [Cruz SCS \& Teixeira AAC; 2010] The evolution of ...; [Dadashpour H \& Jalali A; 2013] An analysis of the ...; [Dadashpour H \& Dadejani M; 2015] Identyfing and prioritizing ...; [Esmaeilzadeh H \& Masoumi L; 2015] Spatial justice analysis ...; [Esri ; 2015] Arc gis10.3 tutorials ...; [Faraji Sabokbar H, et al.; 2014] Explaining Spatial Inequalities ...; [ Federman M, et al.; 2005] The effect of industrialization ...; [Feizpour MA \& Samanpour Z; 2017] Industrial Development ...; [Ghanbari Y, et al.; 2011] The analysis spatial ...; [Ghareghozloo A, Alizadeh M; 2014] Land suitability assessment ...; [Governor General of Ardabil; 2011] Ardabil province planning ...; [Hatami Nejad H, et al.; 2011] Measuring the degree of industrial ...; [Hosseinzadeh Dalir K \& Safari F; 2012] The effect of smart planning ...; [Industry, Mine \& Trade Organization of Ardebil Province "IMTOAP"; 2011] Industries statistics of ...; [Izabella SK, Zsófia V; 2013] Relationship between vegetation ...; [Kamran H, et al.; 2010] Leveling of urban services ...; [Kanbur R \& Venables AJ ; 2005] Rising spatial disparities ...; [Kevinji K \& Pover J; 2007] Guide for sustainable development ...; [Khakpour B \& Baunpouri A; 2009] Leveling of urban services ...; [Khandozzi E; 2005] The realism of justice ...; [Kikha N; 2004] The concept and mechanisms ...; [Masoumi Ashkevari H; 2006] Fundamentals of regional ...; [Miremoezi H; 2010] Islamic economics ...; [Moarefy A, et al.; 2013] Development of industrial ...; [Mohammadi A, et al.; 2010] Determining suitable areas ...; [Mohammadi J, et al.; 2012] Surveying the level of development ...; [Motiee Langroudi H, et al.; 2011] Spatial impact assessment ...; [PoorAhmad A; 2001] Landuse planning and ...; [Pourahmad A \& Fallahian N; 2005] The study of the formation ...; [Pourmohammadi MR; 2009] Urban land use planning ...; [Rezvani MR \& Sahneh B; 2006] Estimation of developmental ...; [Salimifar M; 2009] Measuring industrial ...; [Statistical Center of Iran "SCI"; 2018] Population statistics ...; [Taghvayi M \& Tahmasebi Pour RM; 2011] Dterminig and Analyzing ...; [Tavakoli Nia J \& Nemati A; 2008] The relationship between ...; [Winkler A; 2012] Measuring regional inequality ...; [Ziyari K, et al; 2010] Study and ranking ...; [Zeberdast E; 1999] Industrial development of regions ... 
منجر شد [Winkler, 2012]. اين مساله، به طرح خالشهايى براى تمركززدايى از قطبىشدن توسعه مند النعتى انجاميد. در ايران

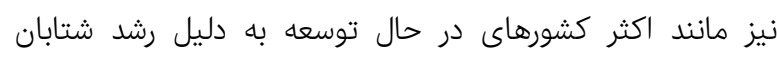

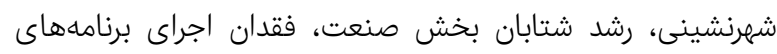

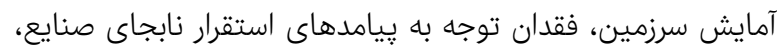

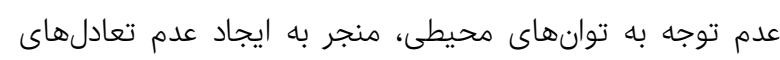

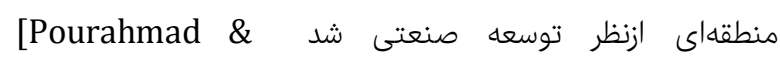

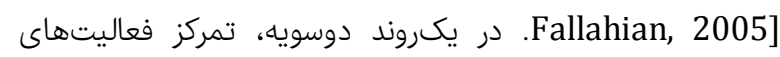
صنعتى در برخى مناطق و فقدان آن در ديكر مناطق ايران، به ديه

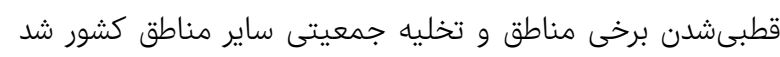

.[Zebardast, 2008]

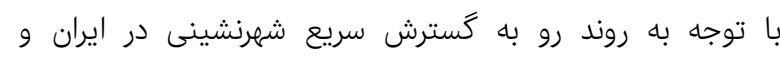

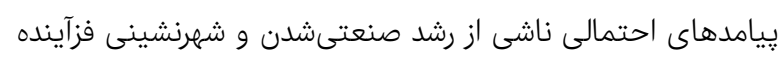

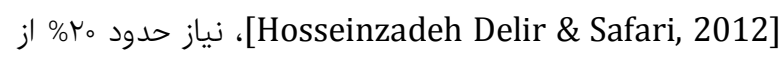
فضاى سرزمينى در سطح كشور به رشد و مكانيابى فعاليتهاى نداى نداز

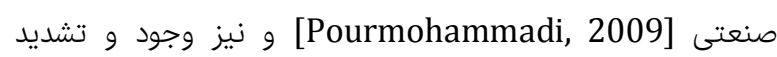

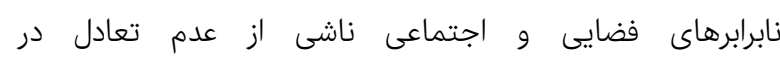

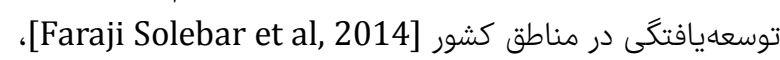

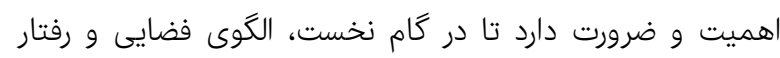

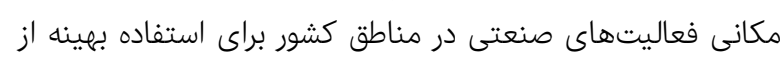

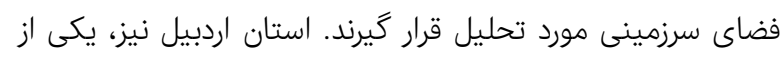

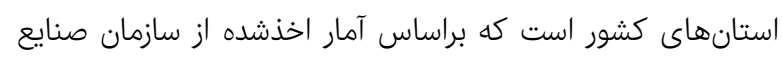

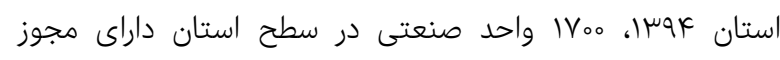

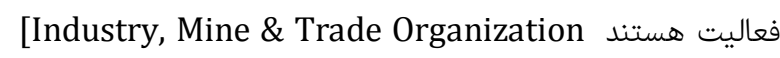
.of Ardebil Province “IMTOAP", 2011] با توجه به اينكه مطابق اسناد و شواهد اوليه، رشد صنايع استان

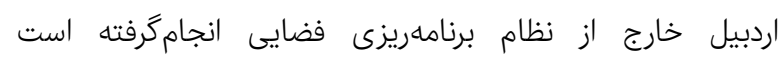
[Sahne, 2005; Rezvani \& Mohammadi, 2015] توجه به قابليتهاى استان اردبيل براى توسعه صنعتى و فقدان

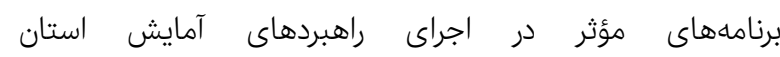

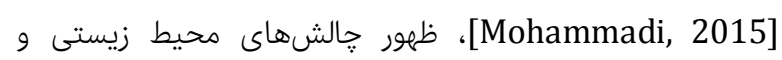

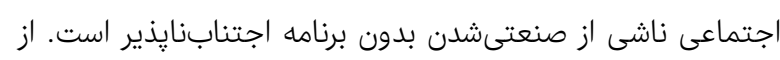

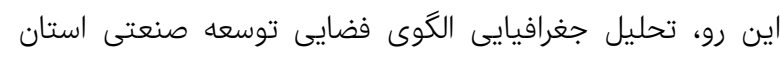

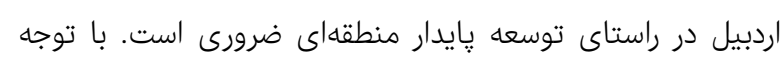

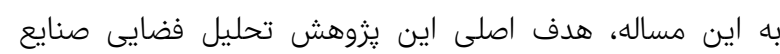

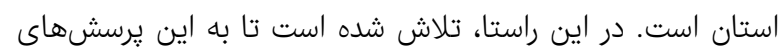

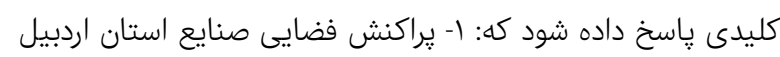

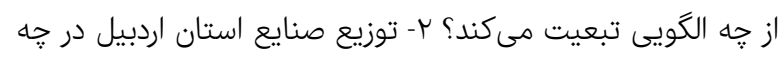

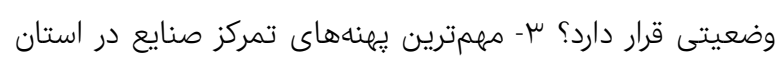

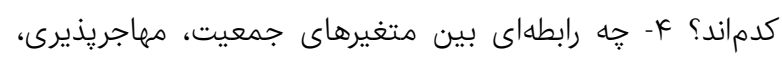

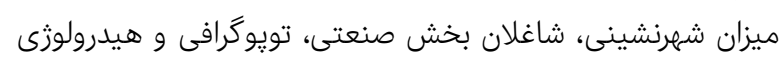

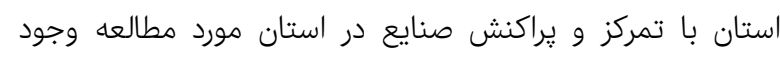
آل حسن و دياو به بررسى نابرابرى منطقهاى در كشور غنا ِِرداخته
تحليل فضيده نورى وعليرضا محمدى الكو و پراكنش صنايع استان

\section{اردبيل با استفاده از آمار فضايى در محيط وايطي}

سييده نورى MA

كروه جغرافيا، دانشكده ادبيات و علوم انسانى، دانشكاه محقق اردبيلى، اردبيل،

ايران

عليرضا محمدى " ايرن

كروه جغرافيا، دانشكده ادبيات و علوم انسانى، دانشگاه محقق اردبيلى، اردبيل، ايران

جكيده

اهداف و زمينهها: يراكنش فضايى نامتعادلٍ صنايع در اغلب مناطق كشورهاى

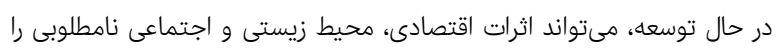

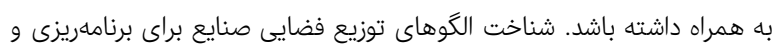

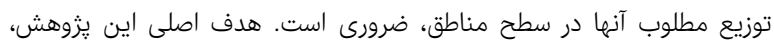

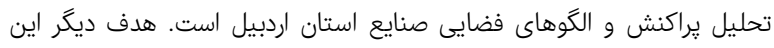

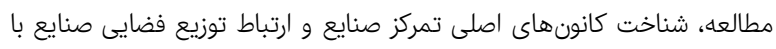
متغيرهاى اقتصادى، اجتماعى و محيطى است.

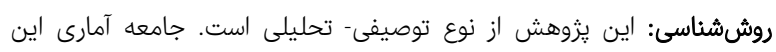

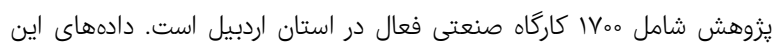

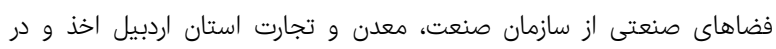

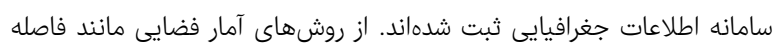

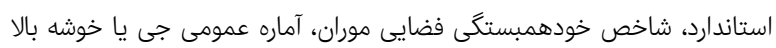

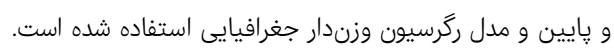

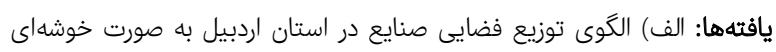

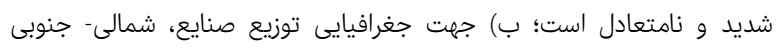

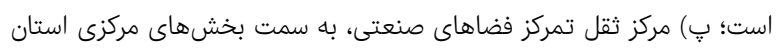

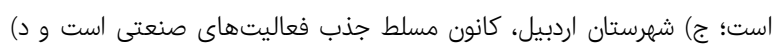

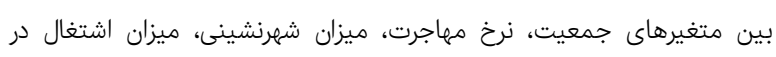

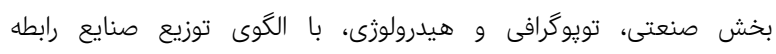

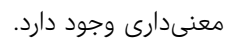
نتيجهگيرى: توزيع صنايع در استان اردبيل از نوع خوشهاى و درعين حال

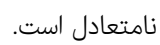
كليدواثمها: تحليل فضايی، الكَو و يراكنش، صنايع، آمار فضايى، استان اردبيل

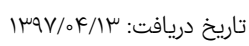

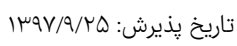
a.mohammadi@uma.ac.ir :نويسنده مسئول:

مقدمه

صنعت به عنوان بخشى از فرآيند رشد و توسعه اقتصادى كشورها،

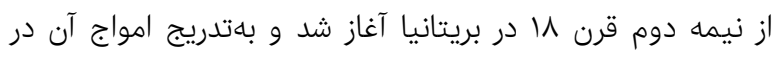

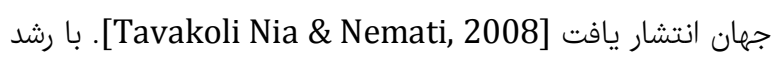

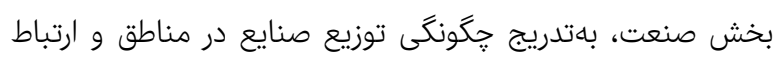

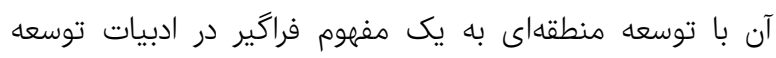

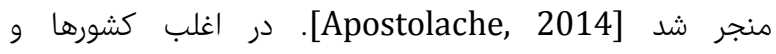
بهخصوص كشورهاى در حال توسعه، شكلگيرى نابرابرى فضايى در توزيع فعاليتهاى صنعتى، به ايجاد عدم تعادلهاى منطقهاى درى داى 


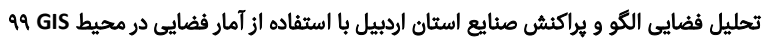

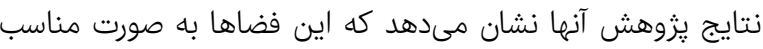

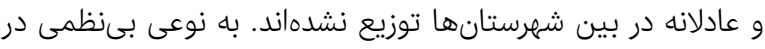

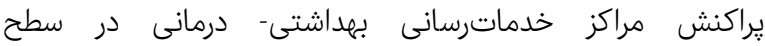

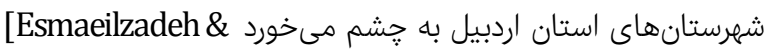
[.Masoumi, 2015] مناسب مكانززينى (خوشههاى صنعتى) در استان اردبيل از روش فردي

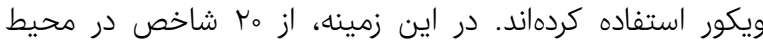

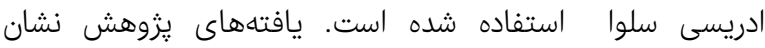

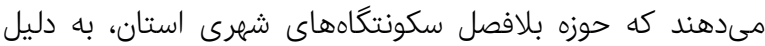
مزيتهاى جغرافيايى، مناسبترين يهنههاى استقرار خوشههاى بهري

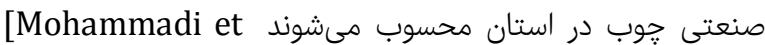
.al, 2016] با توجه به ييشينه ذكرشده از آن جايى كه در اكثر يزوهشهاى

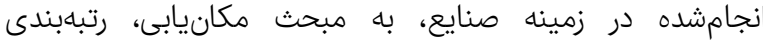

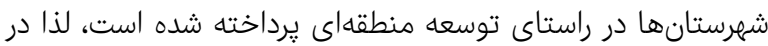

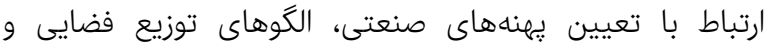

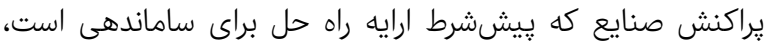

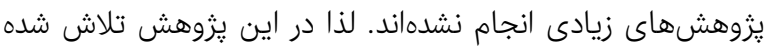
است تا اين شكاف مطالعاتى، برطرف شود.

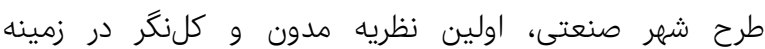
تحليلهاى مكانى و مكانيابى صنايع بود كه در سال $191 V$ و براى

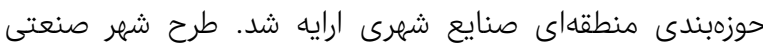

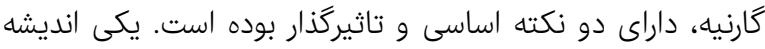
جداسازى مناطق صنعتى از ساير كاربرىهاى شهرى اسرى است كهاس

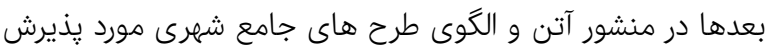

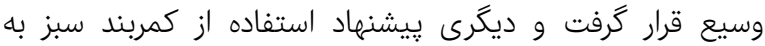
منظور ايجاد حايل ميان مناطق ناسازگًار است، كه امروزه جايگًاه

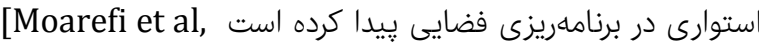
2012]

بيدايش ايده خوشه صنعتى نيز براى اولين بار از طرف مارشال در

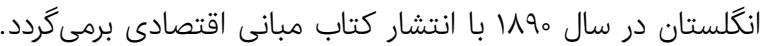

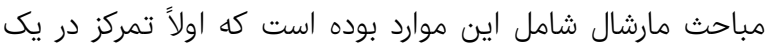

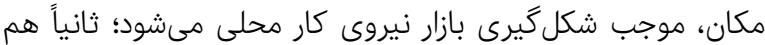

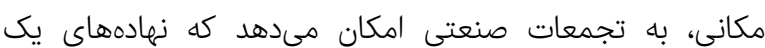

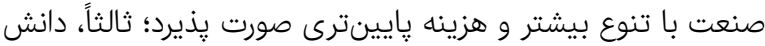

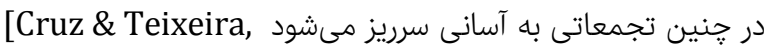
دان در سال 19.9 جارجوب علمى تنئورى مكانيابى صنايع لانهارد

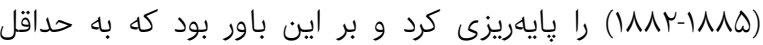

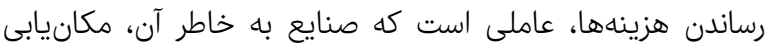

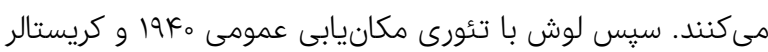
با بسط و توسعه اين تئورى، نظريه مكان مركزى را ارايه كردند و لوني

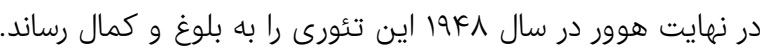

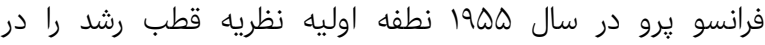

اند و براساس شاخصهاى تركيبى موردنظر كشور غنا را به

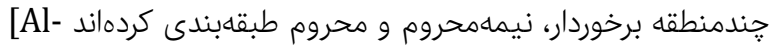

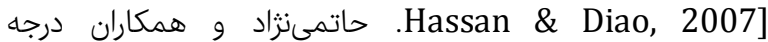
توسعايافتخى صنعتى در مناطق مرزى ايران (مطالعه موردى:

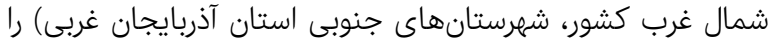

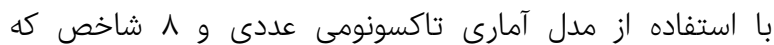
نشاندهنده توسعه صنعتى هستند مورد ارزيابى قرار دادهاند. نتايج

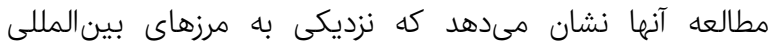

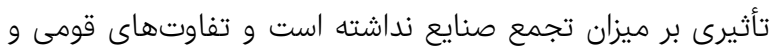
زبانى عامل تعيينكنندهاى در توزيع صنايع در اين شهرستانها

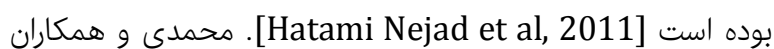
به بررسى نابرابرى شهرستانهاى استان لرستان در بخشهاى

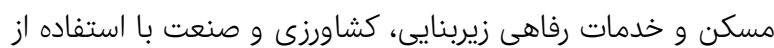

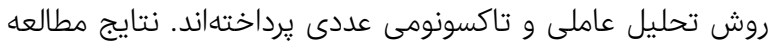

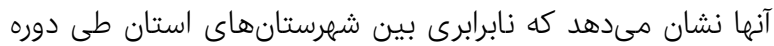

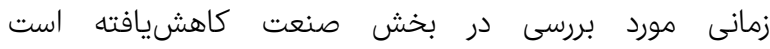
[Mohammadi et al, 2012] قدنبرى و همكاران در مقالهاى باس استفاده از روش ضريب ناموزون موريس و تاكسونومى عددى و با فيا بهرهگيرى از ها شاخص بخش صنعتى، ميزان برخوردارى هر يك مرئ

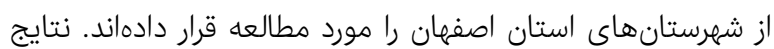
تحقيق آنها نشان مىدهد كه بيشترين بهرهمندى شهرستانها در

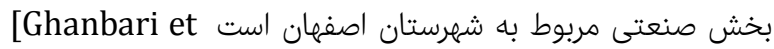
[إمهاشيور و جلالى در مقالهاى به بررسى رابطه بين

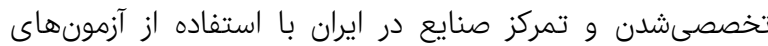

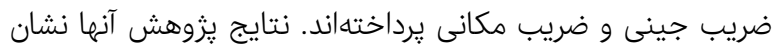

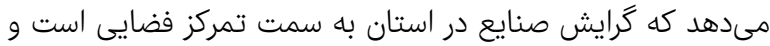

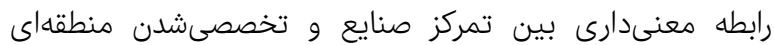
وجود دارد [Dadashpour \& Jalali, 2013]. قرهقوزلو و عليزاده در يزوهش خود، تناسب اراضى براى استقرار صنايع را به روش آنا

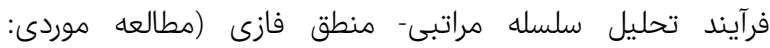

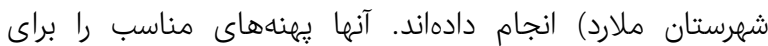
استقرار اين فضاها در سطح شهرستان شناسايى و معرفى كردهاند

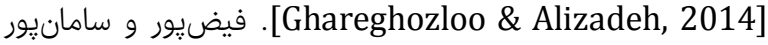
در يزوهشى از طريق روش اقتصاد سنجى داده هاى تابلويى (ينل

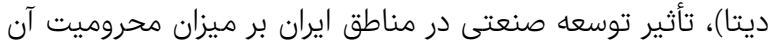

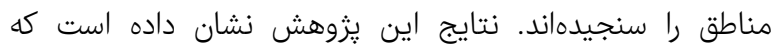
توسعه صنعتى در مناطق جغرافيايى ايران زمينه را براى كاهش

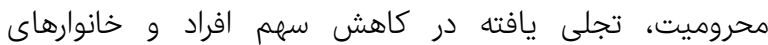

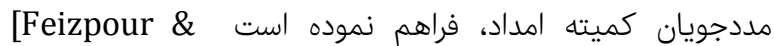

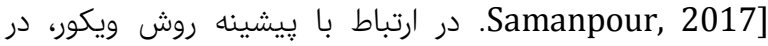

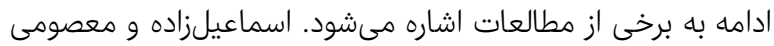
در يزوهش خود به تحليل عدالت فضايى شهرستانهاى استان مرهان

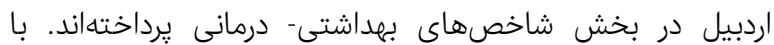

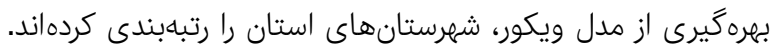


دربركيرنده تعيين مكان آنها به نحوى است كه همه گروههاى

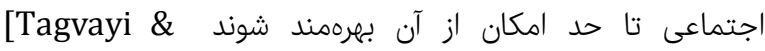
Tahmasebi, 2011] تحقق عدالت فضايى، يكى از مهمترين [Kamran et al, مسايل در اغلب كشورهاى درحال توسعه استئ

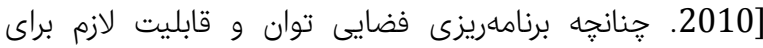
جذب و توزيع مناسب صنايع را نداشته باشد، مناطق بنان بان مسايل

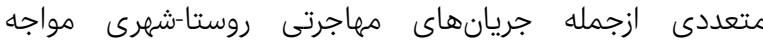

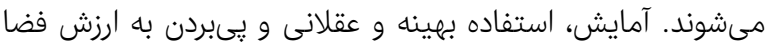

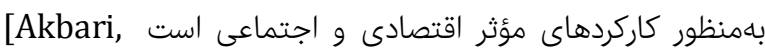

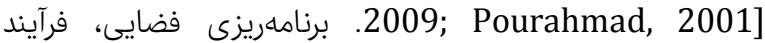
سازماندهى و بهرهبردارى عقلايى از امكانات، منابع و استعدادهاى

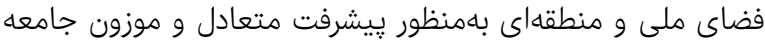
است كه بهرهورى از سرزمين را بهينه مينمايد Masoomi]

.Ashkouri, 2006]

وضعيت موجود ساختار صنعتى استان اردبيل تصويرى از عدم

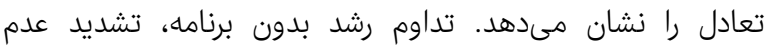

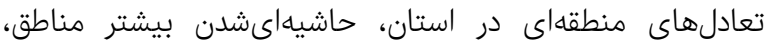

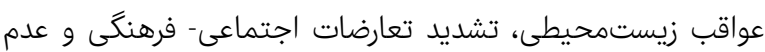

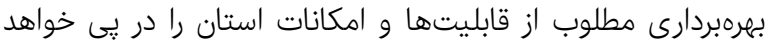
داشت. وسعت گسترده استان، موقعيت منطقاهاى آن در شمال و شمال غرب كشور، برخوردارى از مرزهاى مشترك با كشورهاى مانى

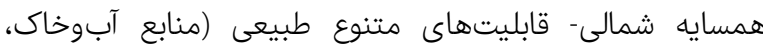

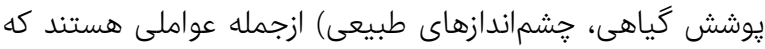

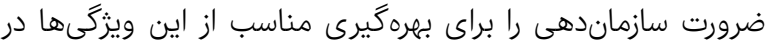

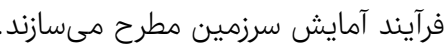

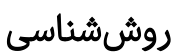

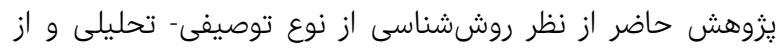

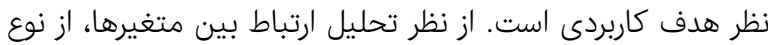

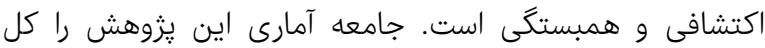
صنايع ثبتشده در سازمان صنايع و معادن استان اردبيل تشكيل

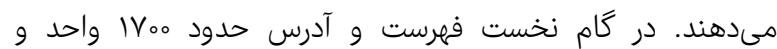

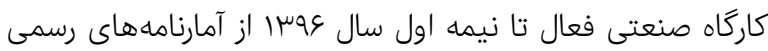

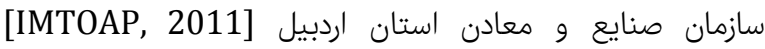

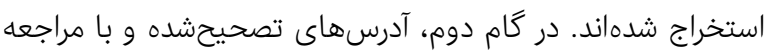

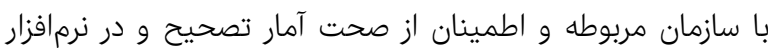

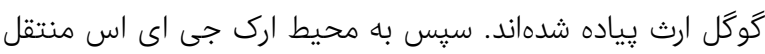

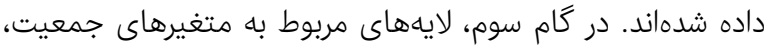

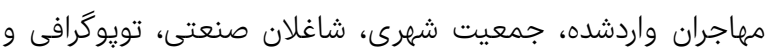

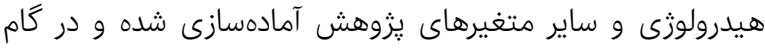

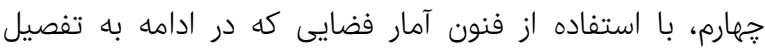

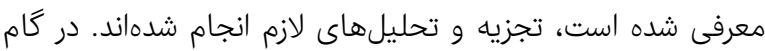
آخر نيز، خروجىهاى حاصل از تجزيه و تحليلهاى آمار فضايى در
مقالهاى مطرح مىكند. وى برى بر اين باور بود كه در مراحل بعدى

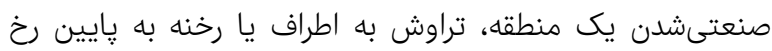

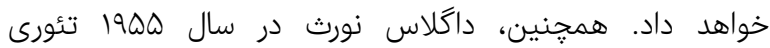
مكانيابى و رشد اقتصاد منطقعاى را مطرح كرد. در سال 190V،

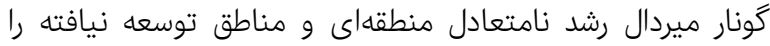

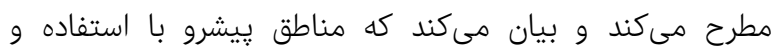

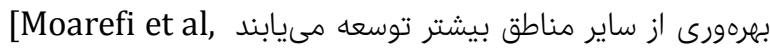

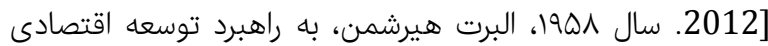
اشاره مىكند و يِيوندهاى رو به جلو و عقب، تأثيرات رخنه به بهات يايين (مناطق پيشرو به مناطق عقبمانده) و تأثيرات قطبىشدان

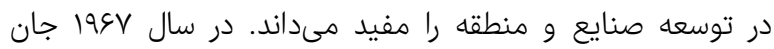

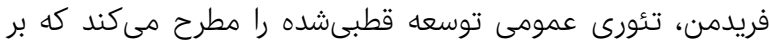

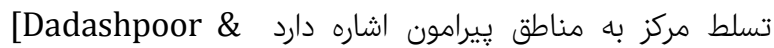

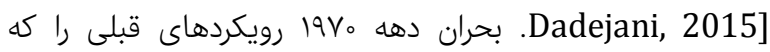

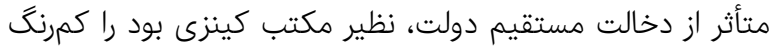

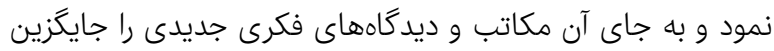
كرد. ميلتون فريدمن، با مخالفت صريح با مكتب كينزى، به آنهائ

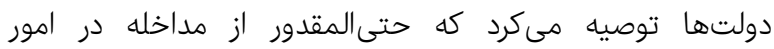
اقتصادى دست بردارند و بكذارند كه مكانيسم بازار به كار كار خود

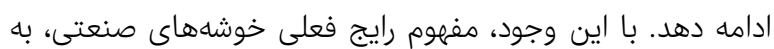

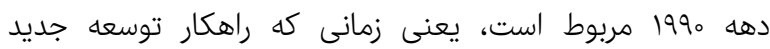

اقتصادى مطرح شد [Moarefi et al, 2012] در קالش براى توسعه مطلوب سرزمينى از طريق صنعتىشدن،

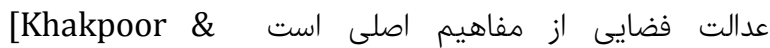
[ Khandozzi, 2005] كه با تحقق آن، افراد، گَروهها و و شخصيتهاى حقيقى و حقوقى به حقوق خود در استفاده از

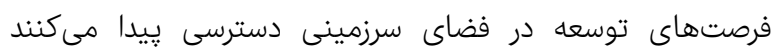
[Mirmoazi, 2008; Kevinji \& Pover, 2004; Kikha, .2004] در مقابل ناعدالتى فضايى به شرايطى كَفته مىشود كه

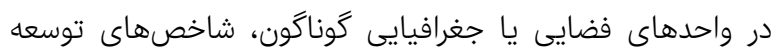

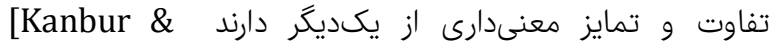

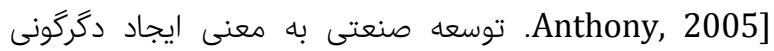
شكل يا تركيب مواد است تا بها ائ اين وسيله مواد خام به به صورت

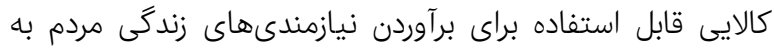

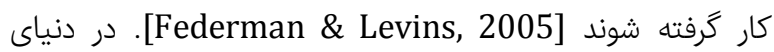

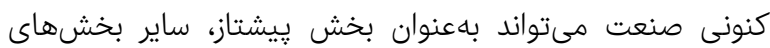
[Akhavan \& Nazari, اقتصادى ران تحت تأثير قرار دهد .2007] در ايران نوسانهاى شديد و فراوان سالانه در آهنگ رشد صنعتى

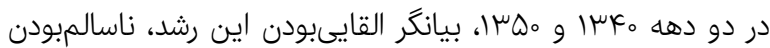
بافت بخش صنعت و مغايرت آن با ساختارهاى اقتصادى،

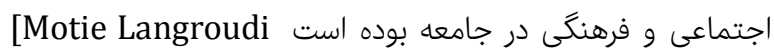
[et al, 2011] در مطالعات جغرافيايى، توزيع متناسب صنايع 


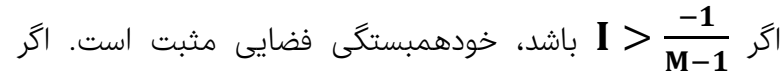

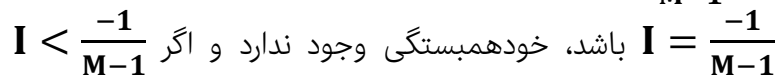
[Izabella \& sófia, باشد، خودهمبستكى فضايى منفى است ناست

.2011]

تحليل خوشه فضايى جند فاصلهاى يا تابع k رييلى

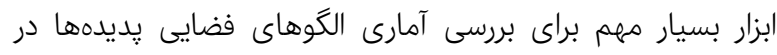

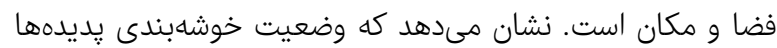

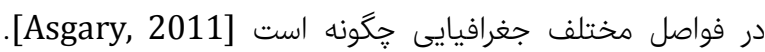

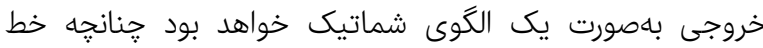
قرمزرنگ بالاى خط آبى در هر فاصلهاى قرار بكيرد نشاندهندا

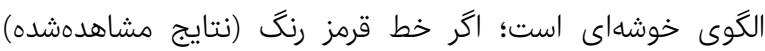

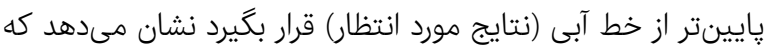

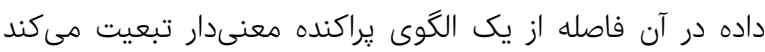

.[Asgary, 2011; ESRI, 2015]

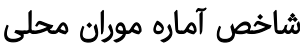

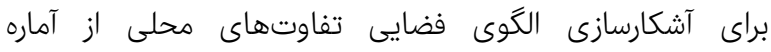

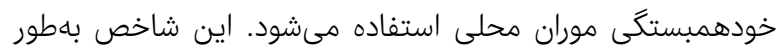

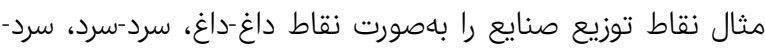

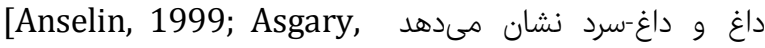

آماره عمومى جى يا خوشههاى بالا و خايين

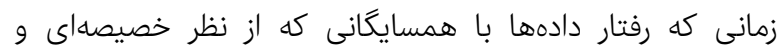

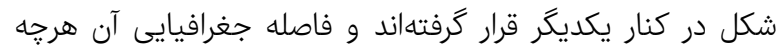

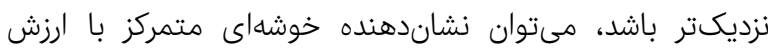

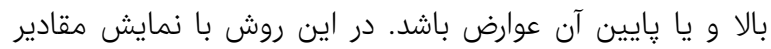

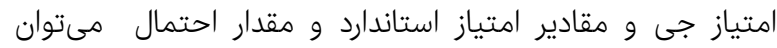

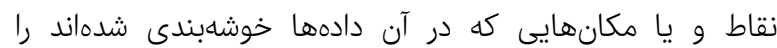

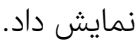

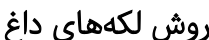

تحليل به روش لكههاى داغ، آماره كتيس را برأ براى كليه عوارض

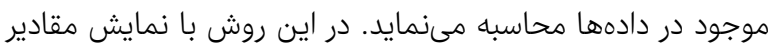

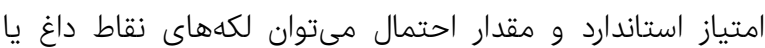
مكانهايى كه در آن دادهها خوشهبندى شدهاند را نمايش داد لـاد

[Asgary, 2011]

مدل ركرسيون وزندار جغرافيايى

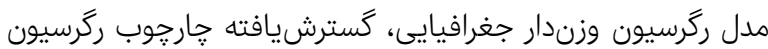

عمومى است [ESRI, 2015] عذرنيا،

قلمرو ائوهش بزوهش استان اردبيل با مساحتى معادل
سيستم اطلاعات جغرافيايى كه شامل جداول و نقشهها بودهاند،

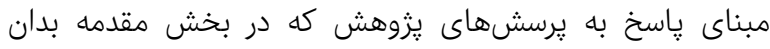

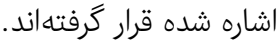

\section{فنون و ابزارها}

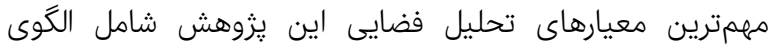

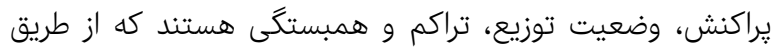
فنون آمارى كه در زير به برخى از آنها اشاره مىشود، استفاده شده

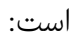

\section{فاصله استاندارد}

اين شاخص ميزان تمركز و يا يراكندگى عوارض بيرامون رامون ميانكين

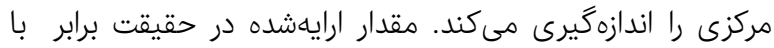
يك دايره بر روى نقشه خواهد بود.

\section{توزيع بيضى انحراف معيار}

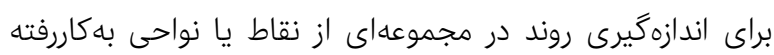

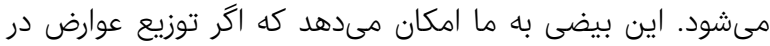

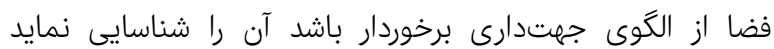

.[Asgary, 2011]

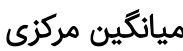
اين روش شبيه به ميانكَين در آمار كلاسيك است. اين شاخص مركائ

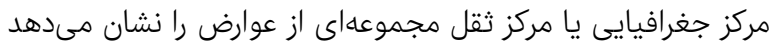

.[Asgary, 2011]

\section{شاخص ميانكين نزديكترين همسايكى}

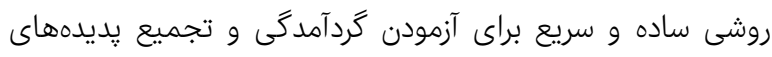

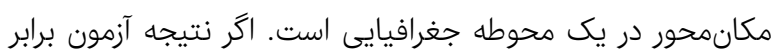

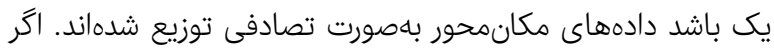

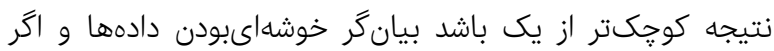

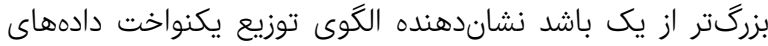

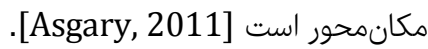

\section{شاخص خودهمبستخى فضايى موران}

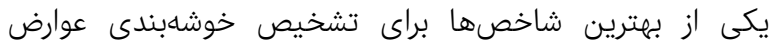

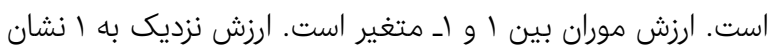

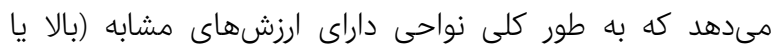

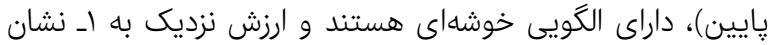

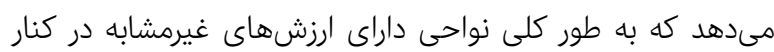

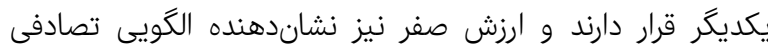

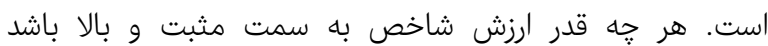

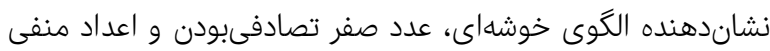

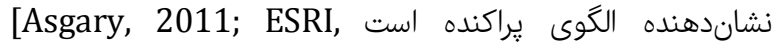


مقدار آماره P-Value برابر با صفر نشان از الكوى خوشهاى با

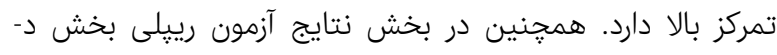

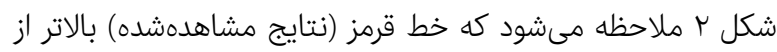

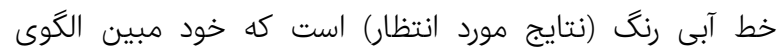

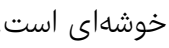

وضعيت توزيع جغرافيايى است

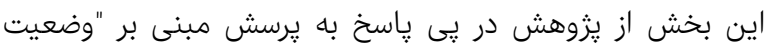

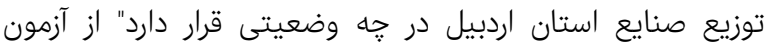

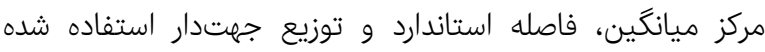

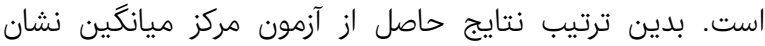

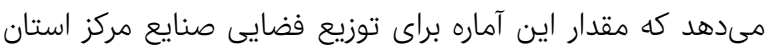

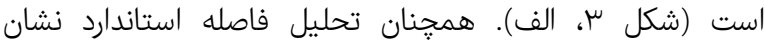

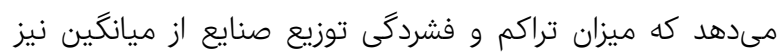

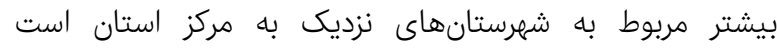

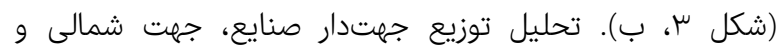

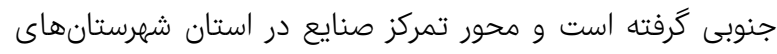

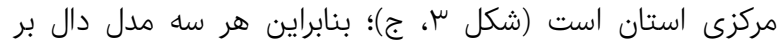

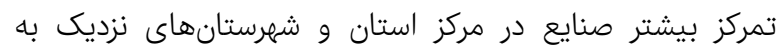
مراكز استان دارد. - مئر

\section{مهرترين يهنههاى تمركز صنايع در استان}

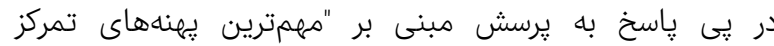

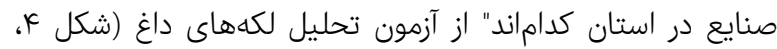

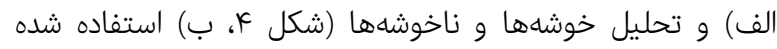

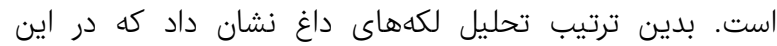

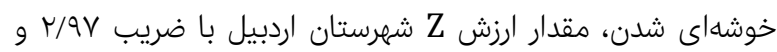

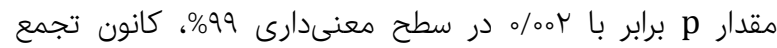

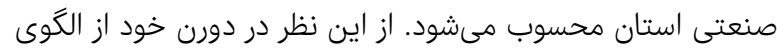
منظم برخوردار است، زيرا منايع و كاركاهها عمدتاً در شهركنهاى

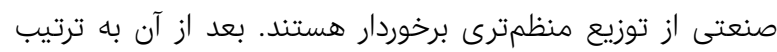

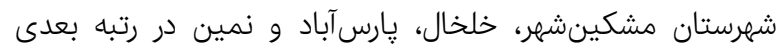

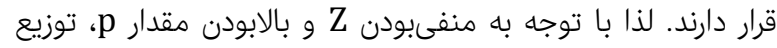

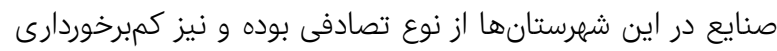

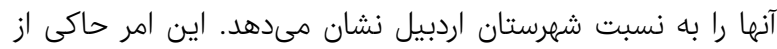

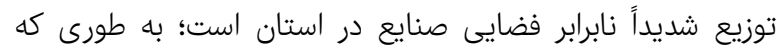

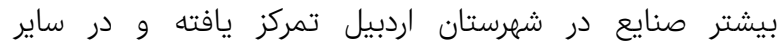

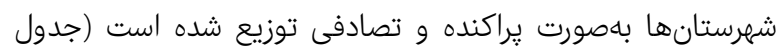

همجنين تحليل خوشها و ناخوشهها در خصوص توزيع فضايى

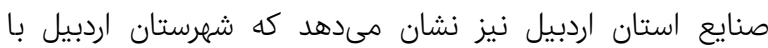

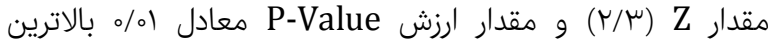

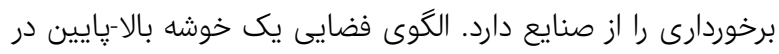
شهرستان اردبيل را تشكيل داده است. ساير شهرستانهاى اردائ استان

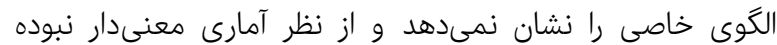

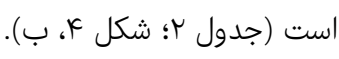

YlYA。o خط استوا و و كرينويج در شمال غرب ايران است. مطابق آخرين سرشمارى در

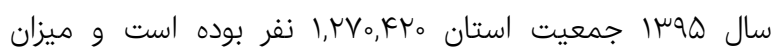

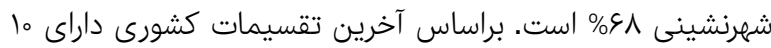

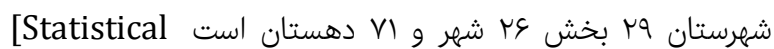
.Center of Iran, 2018]

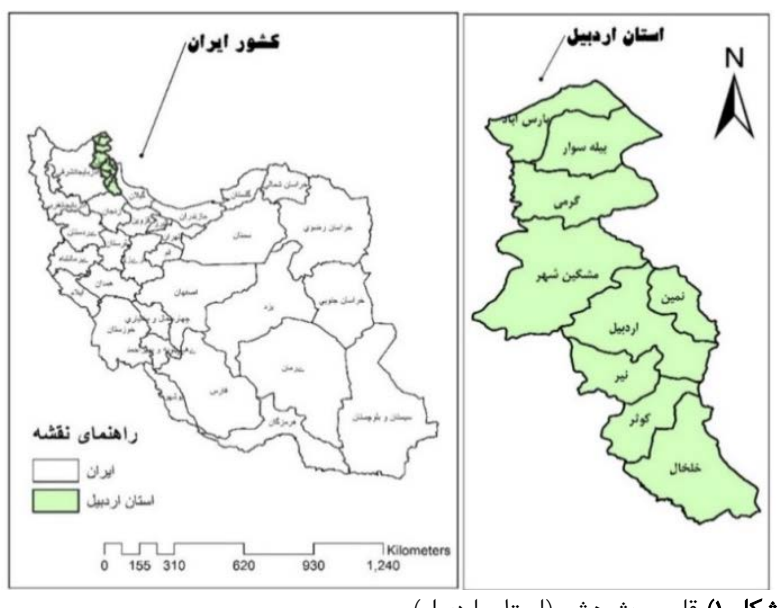

شكل () قلمرو يزوهش (استان اردبيل)

يافتهها الكوى توزيع فضايى صنايع

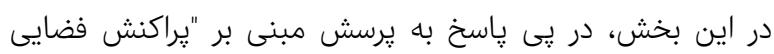

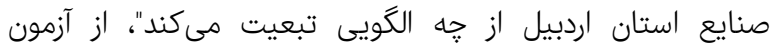

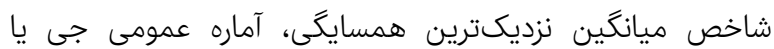

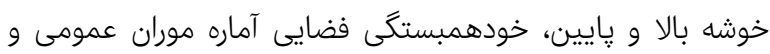

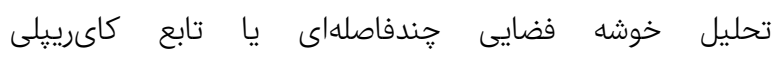

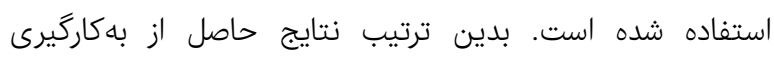

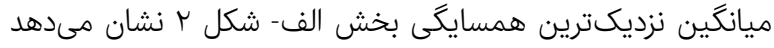

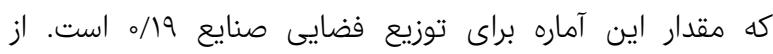
آنجا كه اين مقدار كوجكتر از يك إست (19/1>/19)، نتيجه اينكه

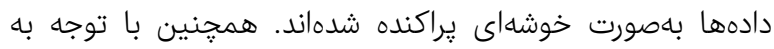

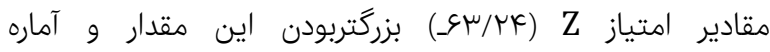
معن P-Value

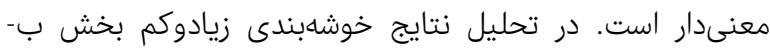

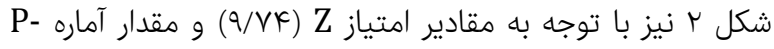

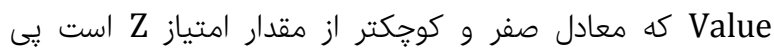
مىبريم كه مقادير دادهها خوشهبندى شده است كادي. ميانه نمودار

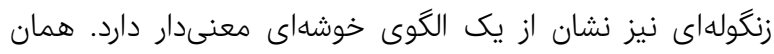
طورى كه در نتايج حاصل از آزمون خودهمبستخى فضان فضايى موران

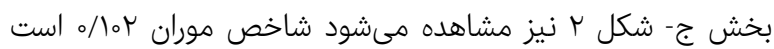

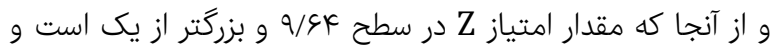




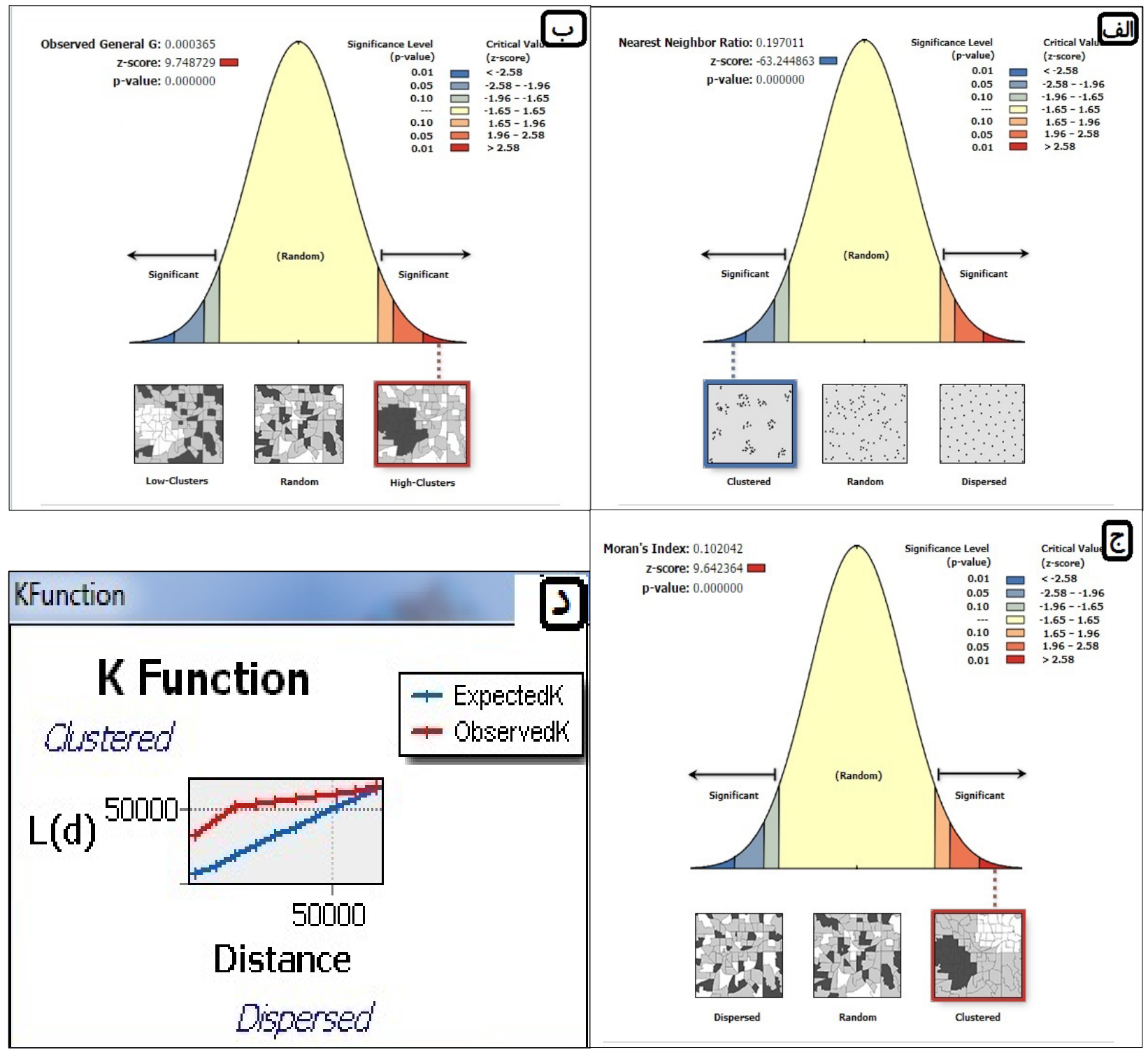

شكل r) توابع شاخص موران براى تحليل الكوى توزيع فضايى صنايع استان اردبيل

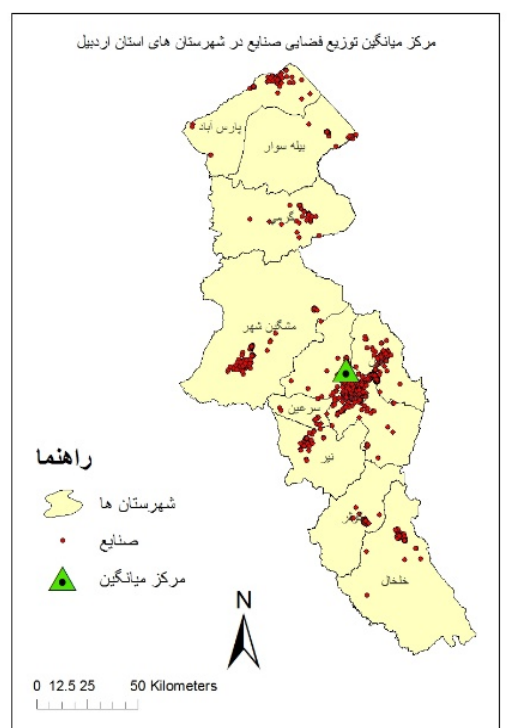

راهنما

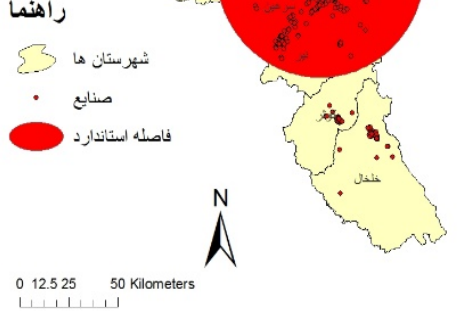

شكل ب) تحليل توزيع جغرافيايى صنايع با استفاده از روشهاى آمار فضايى 

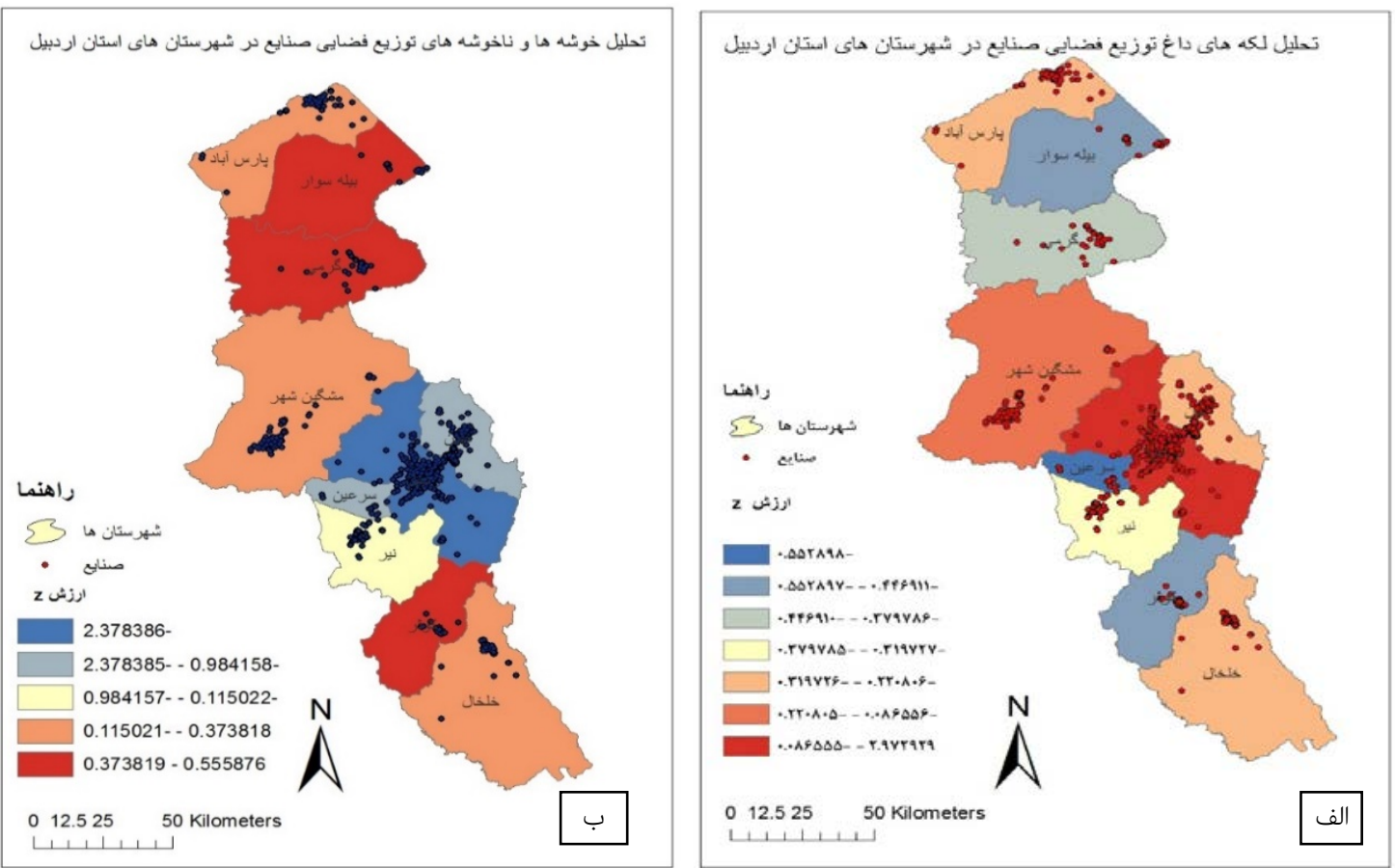

شكل F) تحليل توزيع فضايى صنايع در شهرستانهاى استان اردبيل با روش تحليل لكههاى داغ و خوشهها و ناخوشهها

جغرافيايى استفاده شده است. نتايج ركرسيون جغرافيايى، نشان

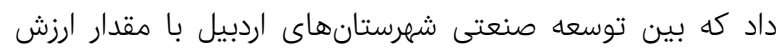

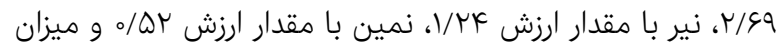

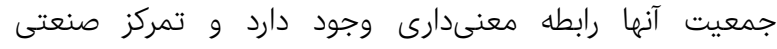
بهتناسب جمعيت اتفاق افتاده است. اين رابطه در درد مورد

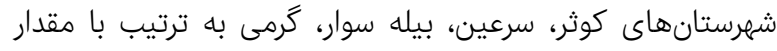

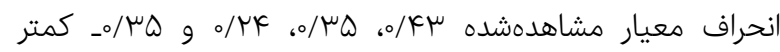

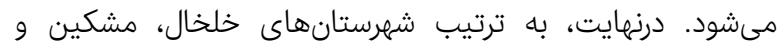

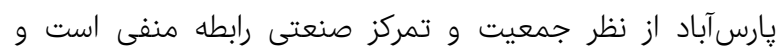
عدالت فضايى در تخصيص تمركز منايع اتفاق نيفتاده و توسعه إناديت كاملاً نامتعادل اتفاق افتاده است (شكل ه، الف).

\section{شهرنشينى و تمركز صنايع}

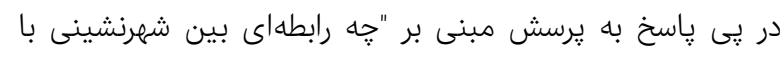

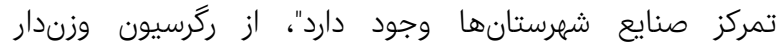

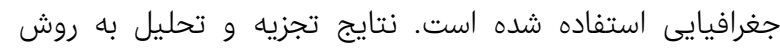

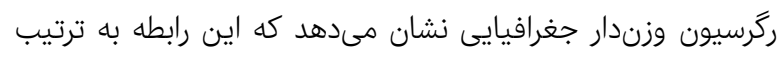

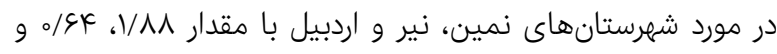

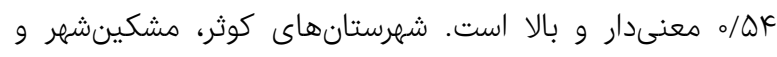

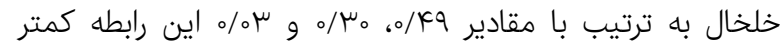

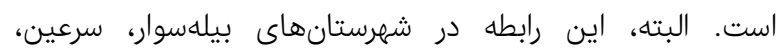
يارس آباد و كرمى وجود ندارد (شكل ه، ب).

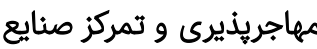

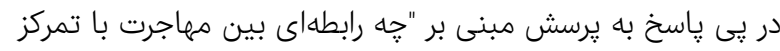

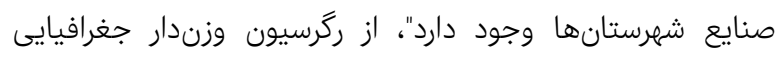

جدول () ارزش z zر تحليل لكههاى داغ

\begin{tabular}{|c|c|c|c|}
\hline Gi-Bin & Gipvalue & Gizscore & شهرستان \\
\hline 。 & -ARrkqK & 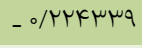 & يارس آباد \\
\hline 。 & -IGMKEYA & 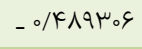 & بيلهسوار \\
\hline 。 & o/Voklok & 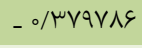 & گرمى \\
\hline 。 & ०/qKI.rD & 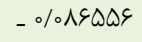 & مشكينشهر \\
\hline 。 & ०/A.okVG & - o/TQYG.r & نمين \\
\hline 。 & o/VkqIVQ & - o/RIQVTV & نير \\
\hline 。 & o/skpquq & - o/k\&\&911 & كوثر \\
\hline 。 & -/ArDYFF & 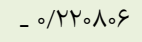 & خلخال \\
\hline 。 & س س & 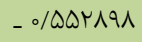 & سرعين \\
\hline$\mu$ & $\%$ & r/qVrqrq & اردبيل \\
\hline
\end{tabular}

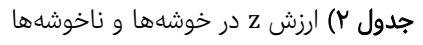

\begin{tabular}{|c|c|c|c|}
\hline Co type & Mip P value & LMi Zscore & شهرستان \\
\hline 。 & $\circ / V_{0} \wedge \Delta K$ & ه/R & يارسآباد \\
\hline 。 & -/DVArQS & 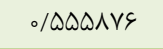 & بيلهسوار \\
\hline 。 & $\circ / \& Y_{\circ} \circ \wedge \Delta$ & - $/ F q \Delta V Y$ & گرمى \\
\hline 。 & 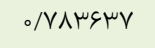 & -/TVKADAT & مشكينشهر \\
\hline 。 & -/MIFART & $-1 / \circ \Delta \Delta V \vee q$ & نمين \\
\hline 。 & -/Q०人kYV & - o/llD.rr & نير \\
\hline 。 & -/G०YGDG & $\cdot / \Delta T_{0} \Delta \wedge \Delta$ & كوثر \\
\hline 。 & $\circ / V Y Y \Lambda \circ \Lambda$ & $\circ / \mu \Delta \xi_{0} k \mu$ & خلخال \\
\hline 。 & - $/ \mu r \omega_{0} \mu \Lambda$ & $-0 / 9 \Lambda<I Q \Lambda$ & سرعين \\
\hline $\mathrm{HL}$ & 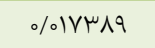 & 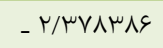 & اردبيل \\
\hline
\end{tabular}

\section{جمعيت و تمركز صنايع}

در پيى پاسخ به يرسش مبنى بر "جه رابطهاي بين جمعيت با تمركز

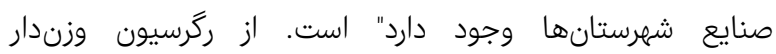


استفاده شده است. از نتايج تجزيه و تحليل به روش ركرسيون

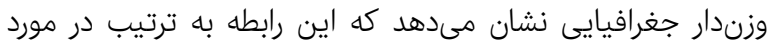

\section{محيط طبيعى و تمركز صنايع}

در اين بخش دو مؤلفه اصلى در ارتباط با تحليط وتيل يراكنش

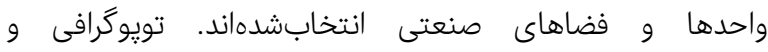

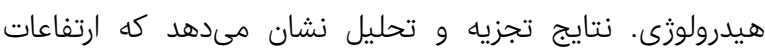

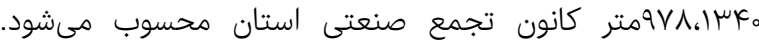

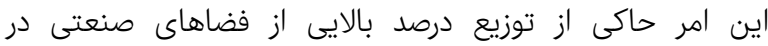

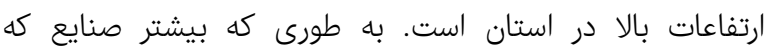

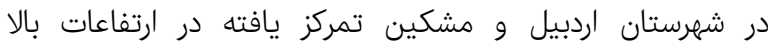

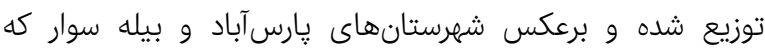

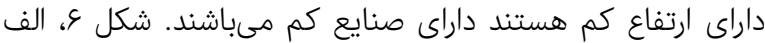
توزيع فضايى صنايع و تويوگرافى شهرستانها را نشان مى مدهند.

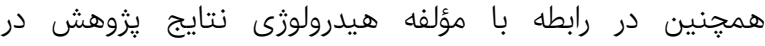

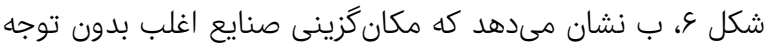
يا با توجه كمتر به حريم آبهاى سطحى در استان صورت كرئ كرفته

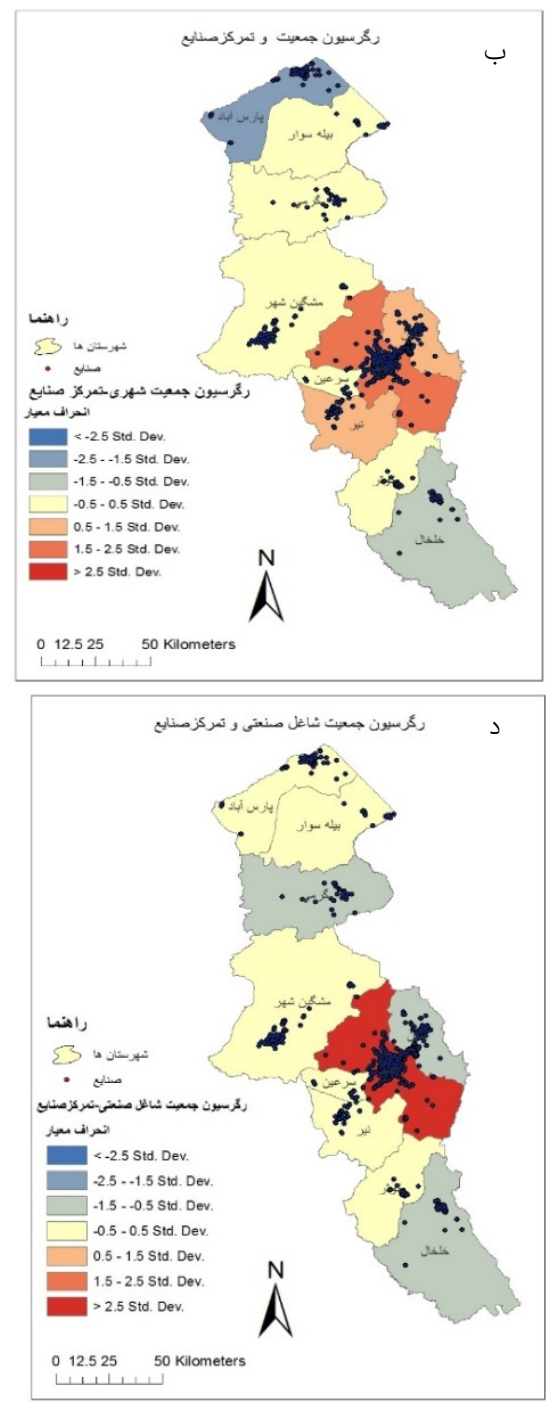

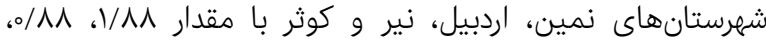

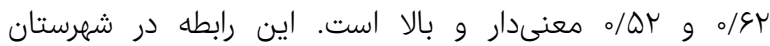
مشكينشهر با مقدار ارزش اس/ه كمتر است. اين رابطه در دراء

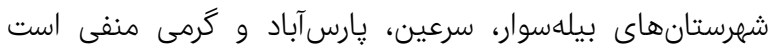

\section{شاغلان صنعتى و تمركز صنايع}

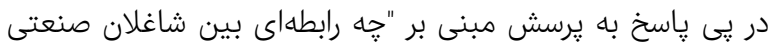

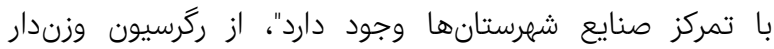

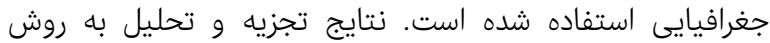

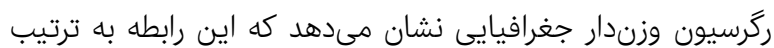

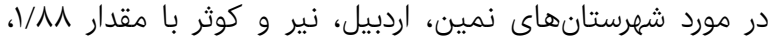

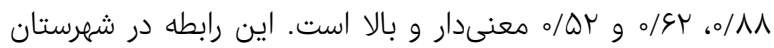

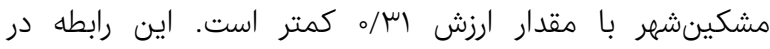

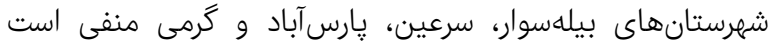
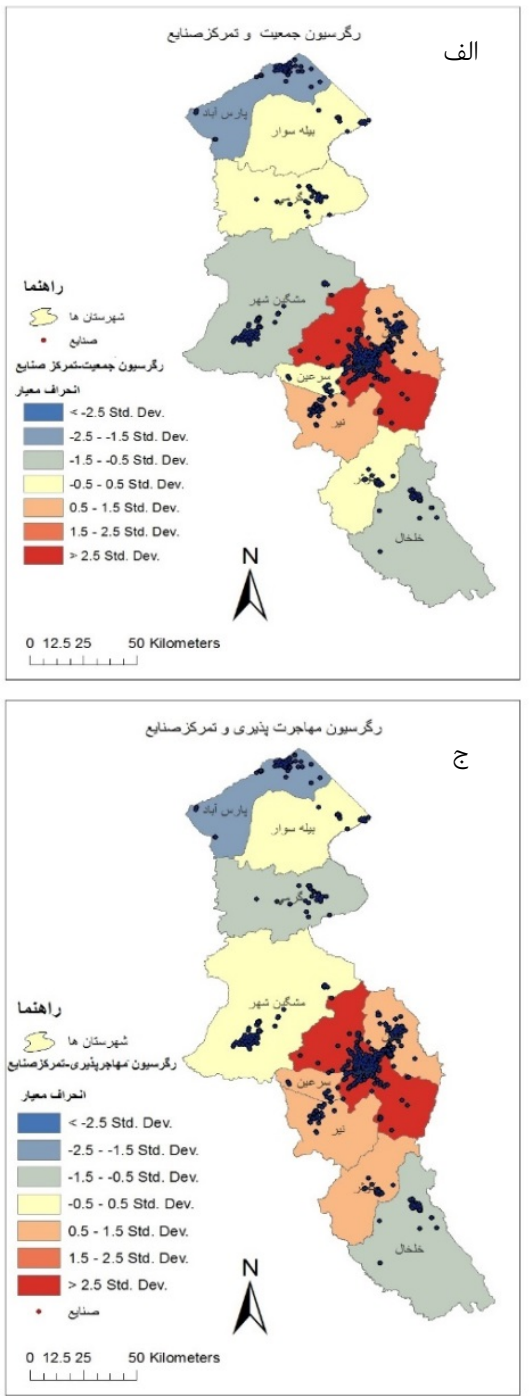

شكل ه) تحليل رگرسيون وزندار جغرافيايى 


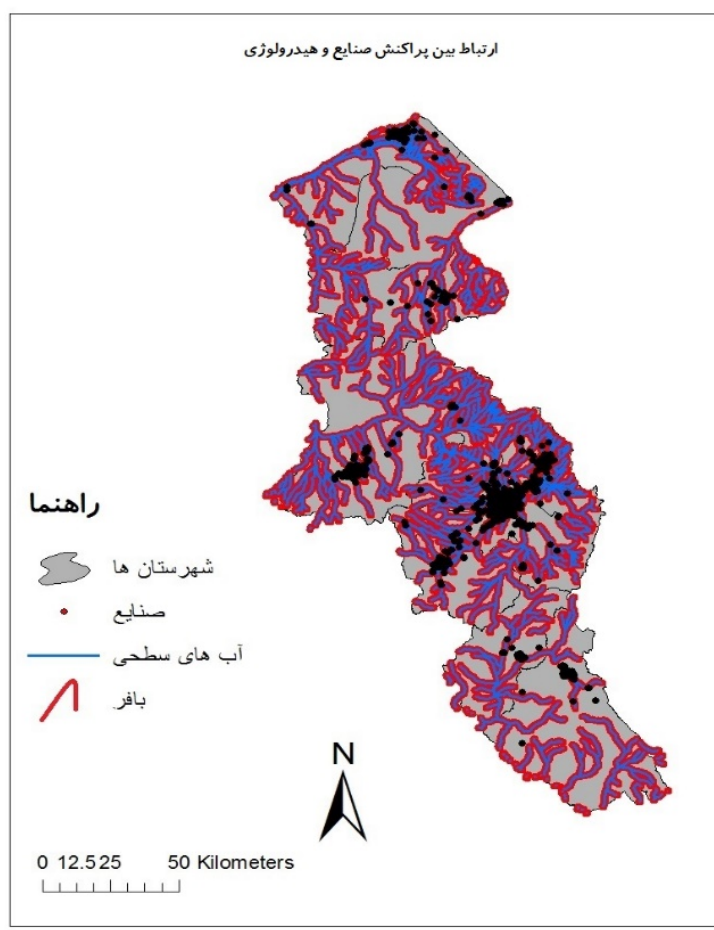

منطقهاى همسويى دارد. همجنين يافتههاى اين يزوهش با نتايج

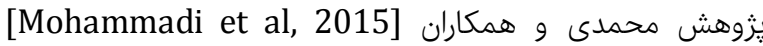
مبنى بر اينكه حوزه بالفصل سكونتگاههاى شهرى هرى استان اردبيل به دليل مزيتهاى جغرافيايى متمركزترين يهنهای هاى صنعتى هستند،

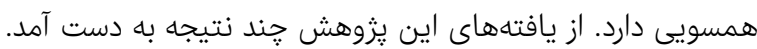
نخست اينكه الكوى توزيع جغرافيايى صنايع استان از نوع خوشهاى شديد است. دوم اينكه توزيع صنايع در درئ سطح شهرستانهاى استان بين مناطق يا نواحى بهصورت ناعادلانه توزيع

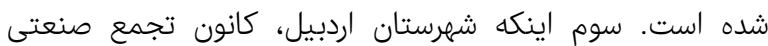

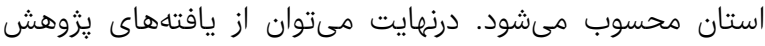

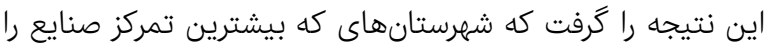

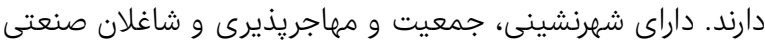

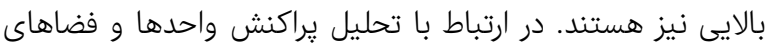

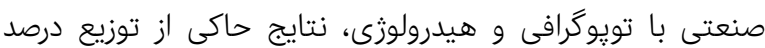
بالايى از فضاهاى صنعتى در ارتفاعات بالا در استان است.

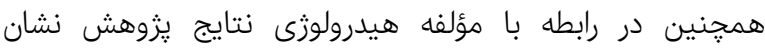
مىدهد كه مكانززينى صنايع اغلب بدون توجه يا با با توجه كمتر به حريم آبهاى سطحى در استان صورت كرفته است.

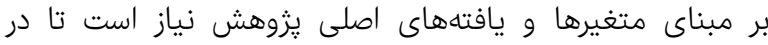

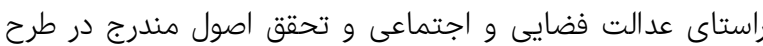

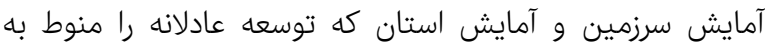
توزيع متناسب فعاليتها در فضاى سرزمينى مىدانند، يِيشنهاداتى

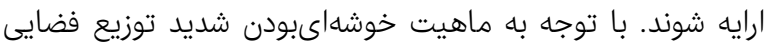
صنايع، نياز است ضمن توجه به اصول آمايش استان و و

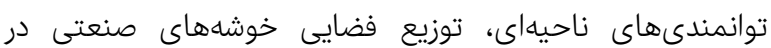

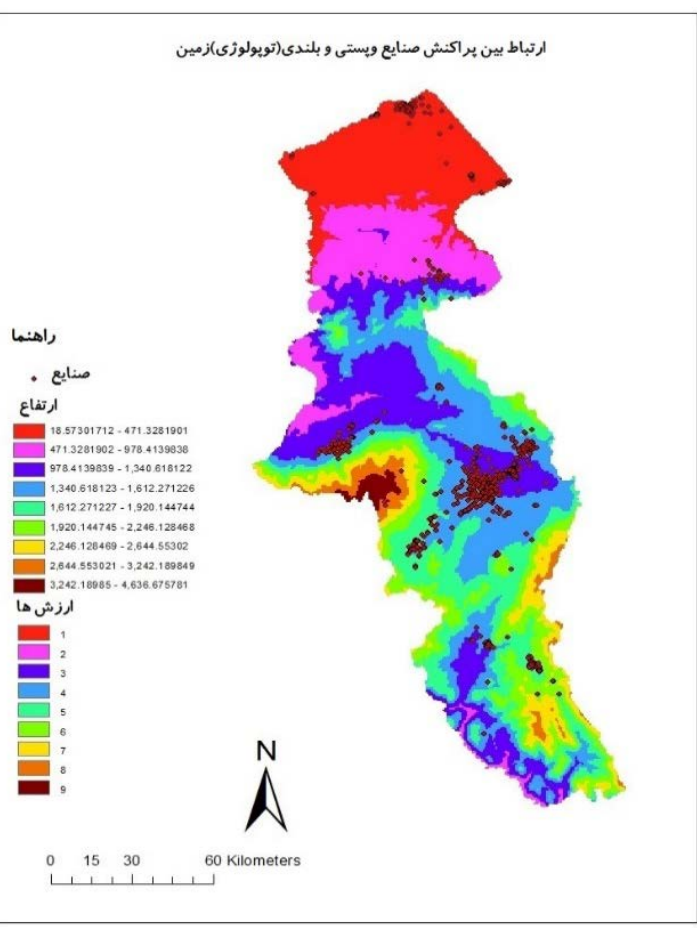

شكل \&) تحليل رابطه بين متغيرهاى محيطى با انباشت صنايع

\section{بحث و نتيجه}

يافتههاى اين يزروهش در بخش فضايى نشان داد كه الگوى توزيع صنايع در استان اردبيل از نوع خوشهاى شديد است. در تبيين

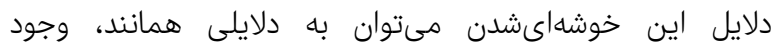

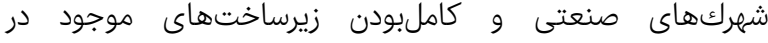
شهرستان اردبيل براى فعاليتهاى صنعتى و فقدان اين شرايط در

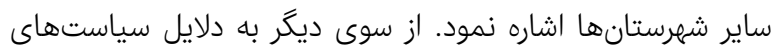

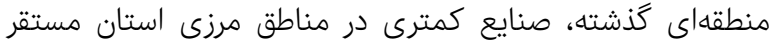

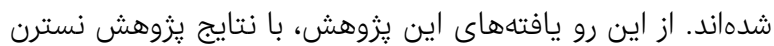
و فتاحى در خصوص عدم تعادل در توزيع شاخصهاى توسعه برونه

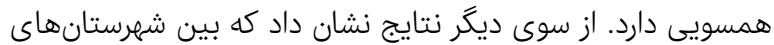

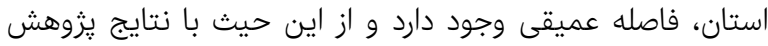
قنبرى و همكاران و اسماعيل زاده و معصومى مبنى بر تفوق مركز استان بر ساير نواحى استانها همسويى دارد : Esmaeilzadeh \& [. با توجه به محروميت شهرستانهاى هممرز با

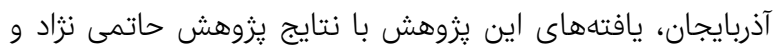

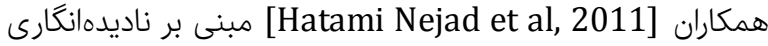
فرصتهاى اقتصادى در استقرار صنايع همسو است. در تبيين اين

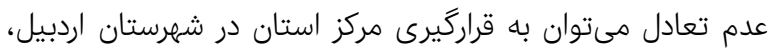

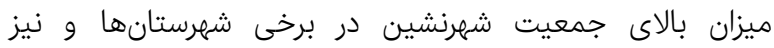

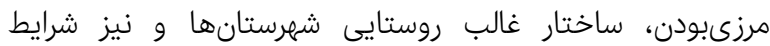

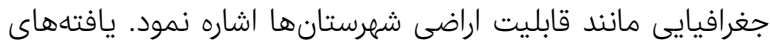

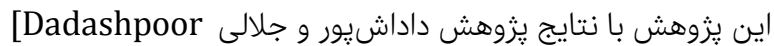

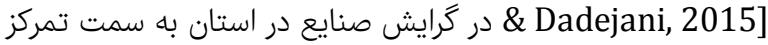
فضايى و رابطه معنىدارى بين تمركز صنايع و تخصصىشدن 
I.Y GIS تحليل فضايى الكو و يراكنش صنايع استان اردبيل با استفاده از آمار فضايى در محيط edition. Tehran: Municipality Information and Communication Technology Organization. [Persian] - Bresnahan T, Gambardell A, Saxenian A (2001). Old economy' inputs for 'New economy' outcomes: (cluster formation in the New Silicon Valleys). Industrial and Corporate Change. 10(4):835-860.

- Cruz SCS, Teixeira AAC (2010). The evolution of the cluster literature: Shedding light on the regional studiesregional science debate. Regional Studies. 44(9):12631288.

- Dadashpour H, Jalali A (2013). An analysis of the pattern of specialization and spatial concentration of industries in Iran. Regional Planning Quarterly. 3(11):118. [Persian]

- Dadashpour H, Dadejani M (2015). Identyfing and prioritizing the radical factors influencing regional competitiveness; (case study: Kurdistan Province). Regional Planning. 5(19):27-42. [Persian]

- Esmaeilzadeh H, Masoumi L (2015). Spatial justice analysis of the cities of Ardebil province in the healthcare indices section using the vikor model. Urban Studies. 7(23):94-104. [Persian]

- Esri (2015). Arc gis10.3 tutorials. Retrieved from www.esri.com. 2015.9.1.

- Faraji Sabokbar H, Varizin N, Sojasi H (2014). Explaining Spatial Inequalities in Health Care Using Decision Electra Model (Case study: Townships of Khorasan Razavi Province). Geography and Regional Development. 12(22):1-18. [Persian]

- Federman M, Levins A, College P (2005). The effect of industrialization on school enrollment and child labor. University of California. Berkeley. 1-37.

- Feizpour MA, Samanpour Z (2017). Industrial Development and Deprivation in Iran's Regions: 20092013. Geographical Research. 32(1):51-63. [Persian]

- Ghanbari Y, Barghie H, Hajarian H (2011). The analysis spatial distribution industrial parameters in districts of Isfahan province about development levels. Spatial Planning. 1(1):17-36. [Persian]

- Ghareghozloo A, Alizadeh M (2014). Land suitability assessment for the deployment of industry-by fuzzy-ahp fuzzy logic hierarchy process analysis (Case study: Malard County). RS and GRS for Natural Resources. 5(4):79-94. [Persian]

- Governor General of Ardabil (2011). Ardabil province planning study report. Deputy planning and budget.

- Hatami Nejad H, AbuBakri T, Ahmadi A, Nayebzadeh F (2011). Measuring the degree of industrial development in the border regions of Iran. (Case study: northwest of Iran, Southern cities of west azarbaijan province). Urban planning Research. 2(7):1-18. [Persian]

- Hosseinzadeh Dalir K, Safari F (2012). The effect of smart planning on urban planning. Geography and Urban Development. 1(1):19-36. [Persian]

- Industry, Mine \& Trade Organization of Ardebil Province "IMTOAP". (2011). Industries statistics of Ardabil Province. [Persian]

- Izabella SK, Zsófia V (2013). Spatial Distribution of Knowledge-Intensive Industries in Hungary. Regional Studies and Spatial Planning. 19(4):431-444.

- Kamran H, Parizadi T, Amini H (2010). Leveling of urban services in Tehran metropolitan regions. Geography and Regional Planning. 1(1):147-164. [Persian]

- Kanbur R, Venables AJ (2005). Rising spatial disparities and development. United Nations University Press. 3:1-8. - Kevinji K, Pover J (2007). Guide for sustainable

شهرستانها بهتناسب توانهاى اقتصادى، محيطى، فناورى و

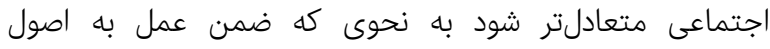
آمايشى، عدالت فضايى و اجتماعى تسهيل شود. با توجه به تمركائ تمركز

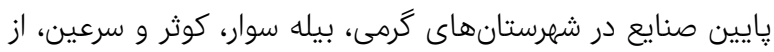

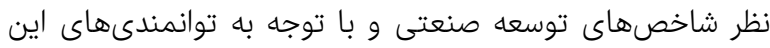

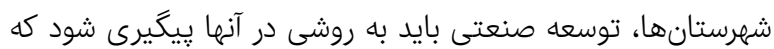

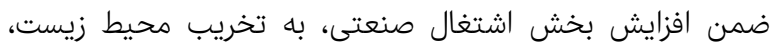
بومَردى و كشاورزى در اين مناطق منجر نشود. با توجه به اله ارتباط

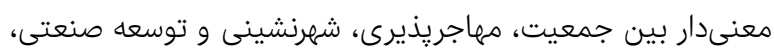
نياز است صنعتى سازى شهرستانهاى استان اردبيل، با برنامههاى

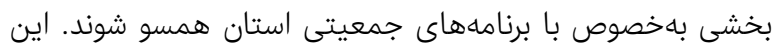
نيز مستلزم اجراى راهبردهاى مندرج در طرح فضايى استان استان است.

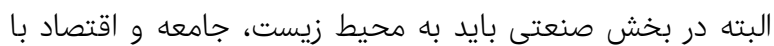

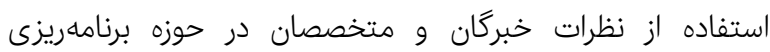

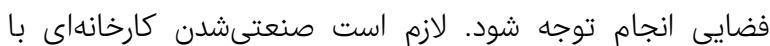

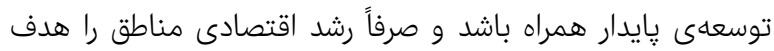
نكيرد. سخن آخر اينكه، بسيارى از مناطق استان اردبيل توانهان مانداى

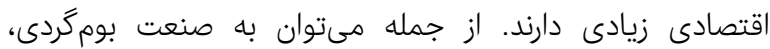
كشاورزى و صنايع دانشبنيان اشاره نمود.

$$
\begin{aligned}
& \text { تشكر و قدردانى: موردى از سوى نويسندكان بيان نشده است. } \\
& \text { تاييديههاى اخلاقى: موردى از سوى نويسندكان بيان بيان نشده است. }
\end{aligned}
$$

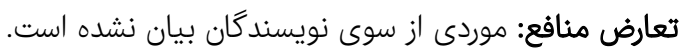

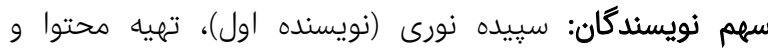

$$
\begin{aligned}
& \text { نقشهها/تحليلكر آمارى (ه\%)؛ عليرضا محمدى (نوان (نويسنده دوم)، } \\
& \text { نكارنده بحث اصلى/روش شناس (هـ\%) } \\
& \text { منابع مالى: موردى از سوى نويسندكًان بيان نشده است. }
\end{aligned}
$$

\section{منابع}

- Akbari M (2009). What is land use planning? Andishehgostar Saipa. 8(93):1-12. [Persian]

- Akhavan H, Nazari R (2007). Performance of Industrial towns in Golestan province and providing an executive decision for their Improvement. Economics. 7(73-74):532. [Persian]

- Al-Hassan MR, Diao X (2007). Regional disparities in Ghana: Policy option and public investment implication, International Food Policy Research Institute Publication. 00693:1-64.

- Yazdani MH (2014). Analysis and leveling of educational development (in Ardebil case studies areas), Educational Planning Studies. 2(4):37-66. [Persian]

- Anselin L (1999). Spatial econometrics (Methods and model). 2nd edition. USA: Springer Publication.

- Apostolache MA (2014). Regional development in Romania-from regulations to practice. Procedia Economics and Finance. 8:35 - 41.

- Ardabil Industrial Townships Company (2011). Report of the comprehensive study and identification of business clusters in Ardebil province.

- Asgary A (2011). Space statistics analysis with GIS. First 
- PoorAhmad A (2001). Landuse planning and balancing in the urban system of the country. Faculty of Literatures \& Humanities. 160(0):479-490. [Persian]

- Pourahmad A, Fallahian N (2005). The study of the formation of industrial axes around Tehran with emphasis on the Karaj axis of Qazvin. Geographical Research. 37(53):173-192. [Persian]

- Pourmohammadi MR (2009). Urban land use planning, First edition. Tehran: Samt Publication. [Persian]

- Rezvani MR, Sahneh B (2006). Estimation of developmental levels of rural areas of aghqala and bandermanar Turkmen districts. Village and Development. 8(3):1-32. [Persian]

- Salimifar M (2009). Measuring industrial development and regional development in razavi khorasan, southern and northern khorasan. Economic Research. 9(4):175196. [Persian]

- Statistical Center of Iran "SCI" (2018). Population statistics of 2016 sensus. [Persian]

- Taghvayi M, Tahmasebi Pour RM (2011). Dterminig and Analyzing of Enjoyment Levels of Booshehr's. Geographical planning of space. 1(2):59-74. [Persian] - Tavakoli Nia J, Nemati A (2008). The relationship between industrial towns with spatial development in ilam province. Housing and Rural Environment, 1(125):74-87. [Persian].

- Winkler A (2012). Measuring regional inequality: an index of socio-economic pressure for Serbia. Zbornik radova-Geografski fakultet Univerziteta $\mathrm{u}$ Beogradu. 60:81-102.

- Ziyari K, Zanjiri M, Kobbari Sorkh L (2010). Study and ranking of the degree of development of cities in Khorasan Razavi province using topsis techniques. Human Geography Researches. 42(72):17-30. [Persian] - Zeberdast E (1999). Industrial development of regions and effective factors in locating large industrial activities. Architecture and Technology. 6(0):38-29. [Persian] development planners. First edition Amirian $S$ Hataminezhad H, Translators. Tehran: CharkheNilofari Publication. [Persian]

- Khakpour B, Baunpouri A (2009). Analysis and analysis of inequality in the levels of development in the areas of Mashhad. Science and Development Magazine. 15(27):182-202. [Persian]

- Khandozzi E (2005). The realism of justice theory in Islamic economics. Islamic Economics. 5(17):113-134. [Persian]

- Kikha N (2004). The concept and mechanisms for the realization of social justice. Political Science. 7(26):163185.

- Masoumi Ashkevari H (2006). Fundamentals of regional planning. Third edition. Tehran: Payam Publication. [Persian]

- Miremoezi H (2010). Islamic economics system. Objectives and motives. First edition. Tehran: Kanoon andishe javan. Publication. [Persian]

- Moarefy A, Etihani V, Ilanlou M (2013). Development of industrial clusters in regional planning. First edition. Mehr sajjad. [Persian]

- Mohammadi A, Ghafari A, Noori S (2016). Determining suitable areas of industrialization (industrial clusters) using multi-criteria decision making models in GIs environment. Journal of Urban Studies. 23:69-86. [Persian]

- Mohammadi J, Abdoli A, Beyranvand M (2012). Surveying the level of development of lorestan province different parts of housing and welfare services of infrastructure. Agriculture and industry. Applied Research of Geographic Sciences. 12(25):127-150. [Persian]

- Motiee Langroudi H, Toorani A, Soleimangoli R (2011). Spatial impact assessment of establishment of industrial towns in rural areas of central minoodasht district. Urban and Regional Researches. 3(9):37-85. [Persian] 